騷音実務講座 $(9)$

\title{
騒音防止技術 (3)
}

中 野 有 朋 $*$

今回は遮音のうちの開口型の遮音と音の伝搬に影響 を与える因子並びに騒音防止に関する感覚的手段，心 理的手段について説明することにする.

\section{1. 開口型の遮音}

これは，例えば送風機の吸込口に空気は通すけれど も音は通さない消音器などをつけて吸込口からでる送 風機の騒音を遮音することである。

消音器は音の吸収, 反射, 干渉などを利用した減音 を目的として用いられる装置である。

消音器は 1 つの装置として設計, 製作され使用され

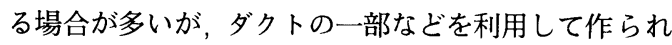
ることも少なくない。

\section{(1) 消音器の消音効果}

消音器の消音効果を表すのに普通透過損失が用いら れる.これは図一 1 において，消音器入口における入 射音のエネルギーと, 出口における透過音のエネルギー をdB単位で表した時の両者の差であり， $\mathrm{TL}=10 \mathrm{log}$ $\frac{I_{1}}{I_{3}}=L_{1}-L_{3}(\mathrm{~dB})$ で表される.

消音器は色々な条件て使用されるので実際問題にお いては，まず消音器の透過損失特性を検討し，次にこ れに音源, 開口端, 設置位置の影響などを考慮して実 際の消音効果がきめられる.

\section{(2) 消音器の種類と透過損失}

消音器は消音機構からいくつかの種類に分類される. よく使用される消音器の構造, 透過損失など表 1 にま とめて示す.

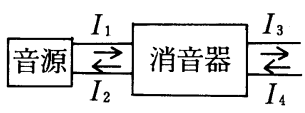

図-1 消音器の消音効果

*石川島播磿重工業㹯技監

Aritomo NAKANO
(1) 吸音ダクト型消音器

これは表 1 の 1 に示すように, ダクト内面にグラス ウールやロックウールなどの多孔質吸音材料を貼った 消音器である. 音が中を伝わる時, 吸音材料にあたっ て吸音される。

この消音器は，送風機など空気流をともなう機械の 騒音防止に多く用いられる．また高音部の騒音低減に 有効である.この消音器のTLを表すあのとしては表 に示すSabineの式があり，簡単で実際によく用いら れる。

この式はおよそ $f=\frac{c}{D}(\mathrm{~Hz})(c:$ 音速, $D:$ ダクト 断面寸法, 直径または短辺の長さ) 以下の周波数範囲 で成立つ.この式ではTLは吸音率に比例して大きく なるが, 実際の吸音ダクト型消音器の透過損失特性は およそ表に示すようになる．TLが最大になる周波数 はダクトの断面寸法Dによって決まる。

まず消音しようとする周波数が $f(\mathrm{~Hz})$ の場合, $D$ を $\frac{c}{2 f}<D<\frac{c}{f}$ にする. 例えば $f=1,000 \mathrm{~Hz}$ の場合, 17

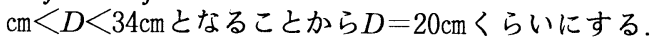
そうすると $1,000 \mathrm{~Hz}$ 付近のTLがもっとも大きくなる. ダクトの断面寸法が決まっている時は，その寸法が $D$ より小さい場合には拡大し，大きい場合には分割する. 分割する場合には，空気の流机抵抗などを考慮して短 冊や十文字形などに分割される。このように分割され た吸音ダクト型消音器をセル型，あるいはスプリッタ 型消音器とよんでいる.

次に $f=\frac{c}{D}(\mathrm{~Hz})$ 以下の周波数についてSabineの 式によってTLが算出される。

ダクトの曲がり部分に吸音材料を内ばりした吸音ダ クトでは, 一般に曲率が大きいほどTLは大きくなり， また吸音材料の吸音による減音も加わり，直管の吸音 ダクトよりもTLは大きくなる. 直管ダクトに多孔質 吸音材料を内ばりした吸音ダクト（表 1 の 2 ）の場合, TLはおよそ表に示すようになる. $D=1.2 \mathrm{~m}$ の場合 500 
表 1 消音器の種類と透過損失特性

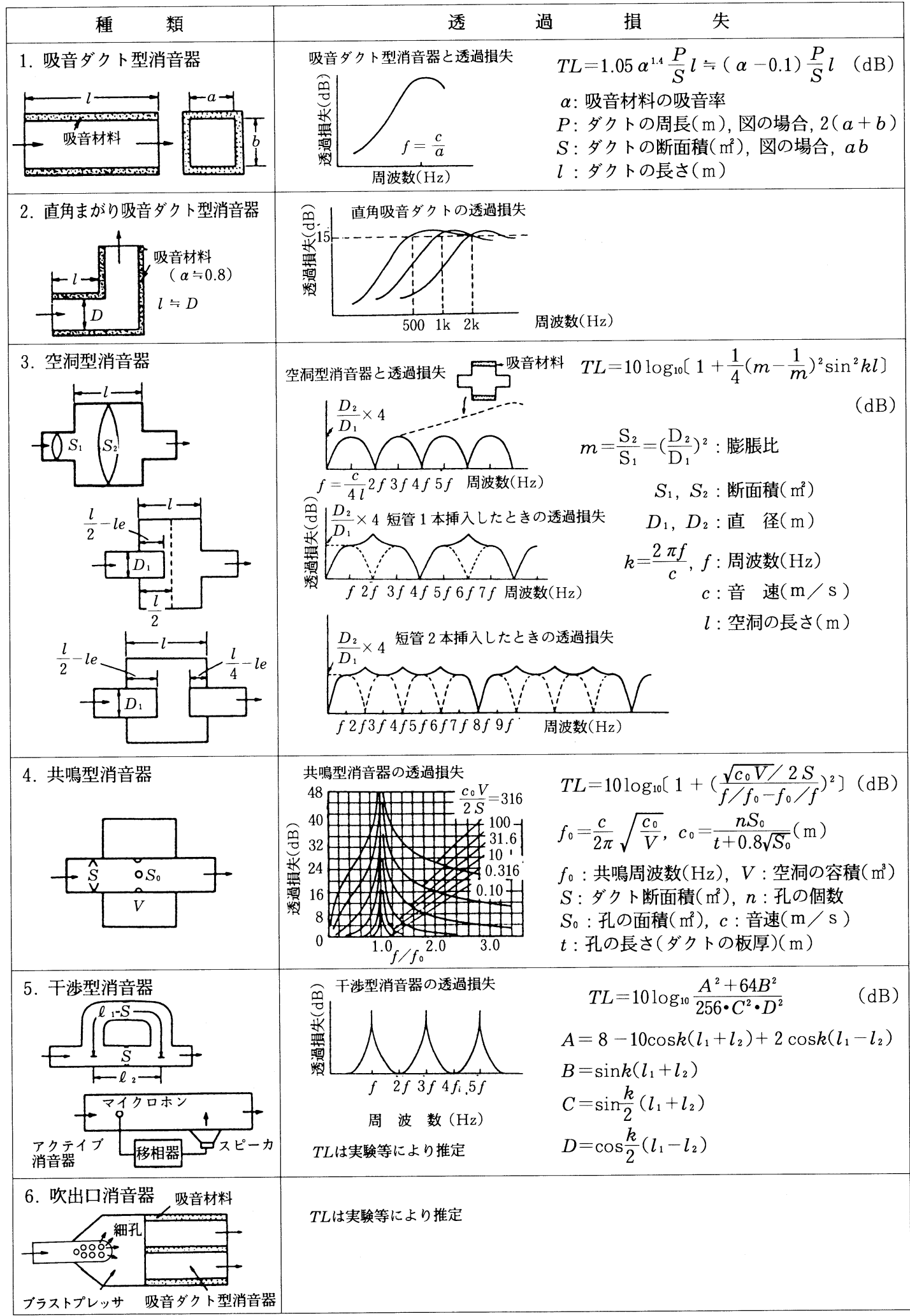


$\mathrm{Hz}$ 以上で15dB，Dが半分になるごとに， 2 倍の周波 数で同じ程度のTLが得られる。

(2) 空洞型消音器

これはダクトの断面積を変化させた構造の消音器で ある（表 1 の 3 ). 消音器に入射した音は断面の変化 部において反射されて低減する.

この種の消音器は主として, 低・中音部の騒音低減 に有効であるが，多孔質吸音材料を併用すると高音部 の減音にも有効である。したがって送風機, 圧縮機お よびエンジンなどの各種の機械の吸, 排気口からの騷 音低隇に広く用いられている。 この消音器のTLは表 に示すと抽であるが，これは $f=1.22 \frac{c}{D_{2}}(\mathrm{~Hz})$ 以 下の周波数範用で成り立つ. 周波数 $f=\frac{c}{4 l}, 3 f, 5 f, \cdots$ …(Hz) でTLは最大になり, よく使われる $\frac{D_{2}}{D_{1}}=2$ 〜 3 の範囲ではおよそ $\frac{\mathrm{D}_{2}}{\mathrm{D}_{1}} \times 4(\mathrm{~dB})$ となる. しかし周 波数 $2 f, 4 f, 6 f, \cdots \cdots(\mathrm{Hz})$ では 0 になる.

この消音器の空洞部に多孔質吸音材料を内ばりする とTLは鎖線に示すように高音部で改善される.また 空洞部に短管を扱入することによって, TLが改善さ れる。

なお図中のl $e$ は管端補正長さで断面が円の場合, 直 径を $D_{1}$ とするとl $l_{e} \fallingdotseq 0.8 D_{1}$ である．

この消音器を $2 つ$ 接続した場合のTLは, 一般には それぞれのTLの和にならないが， $l_{0}$ (接続管の長さ） ミlであればそれぞれのTLの和と考えてよい.

(3) 共鳴型消音器

これはダクトの周囲に空洞を設けて, 小さな孔をあ けた構造の消音器である (表1の4). 孔と背後の空 洞が共鳴器を形成し, その共鳴周波数と一致する周波 数の入射音は共鳴吸収によって吸音されて低隇する.

この消音器は, 低, 中音部の特定周波数成分のレベル がとくに大きい騒音の低減に有効であり, 往復式圧縮 機やディーゼルェンジンなどの吸, 排気口からの騷音 低減に用いられることがある。

この消音器のTLは表に示すようになる.

なお同型の消音器を接続して使用する場合には，共 鳴周波数付近のTLが非常に大きくなる.

(4) 干渉型消音器

比較的低音部の特定周波数成分のレベルがとくに大 きい騒音の低減に, 干渉型消音器（表1の5) が用い られることがある。これは入射音の通路を 2 つにわけ て, 一方 $\left(l_{1}\right)$ を他方 $\left(l_{2}\right)$ より長くして, 再び通路 を 1 つにしたもので, この 2 つの音の干渉によって音 は低隇する。
なお通路の断面寸法は音の波長にくらべて小さくす ることが必要である.

この消音器の透過損失は表に示すとおりである.

$l_{1}-l_{2}=\frac{\lambda}{2}, l_{1}+l_{2}=\lambda$ を満足する周波数 $f$ および $3 f, 5 f, \cdots \cdots(\mathrm{Hz})$ でTLはもっとも大きくなる.し たがって $f(\mathrm{~Hz})$ において最大のTLを得るためには $l_{1}=\frac{3 c}{4 f}, l_{2}=\frac{c}{4 f}(\mathrm{~m})$ にすればよい.

なお以上にのべた透過損失の，例えばオクターブバ ンドごとの透過損失は, 各オクターブバンド内の周波 数 $1 \mathrm{~Hz}$ ごとの透過損失 (各式の計算値) のdB和とし て求められる.

(5) 能動型消音器

干渉型消音器の一種で, アクティブ（能動型）消音 器とよばれる消音器の研究が最近進んでいる。これは 表 1 の 5 に示すように, 音源からの音をマイクロホン

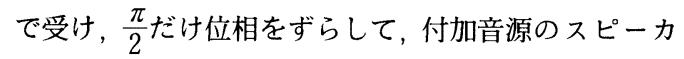
から逆位相の音をだし，この音と音源からの音を干渉 させて消音する消音器である。

実用上未解決の問題が多いが，ダクトの中を伝わる 騒音の低減などに使用される。この消音器において, 適確に干渉をおこすためには, 次の 4 つの基本的条件 を満足する必要がある.

1つは消音しようとする音が純音，または少なくと あ特定周波数成分が, 顕著に卓越している音でなけれ ばならないことである. 騒音のように色々な周波数成 分からなる複合音の場合には，騒音スペクトルによっ て干涉の結果, すなわち消音器の透過損失が異なる, どうなるかは, 実験的に確かめる以外に方法はない，

2つ目は，消音しょうとする音と，スピーカからで る音がぴったり重ならなければならないことである。 広い空間にでている音に別な音を出して重ねることは 不可能に近いが，これにくらべてダクトの中を伝わる 音のように空間に拡がる前の音に重ねあわすことは比 較的簡単であるが, その場合でも, スピーカの数, 取 付け位置などによって重なり方が異なる。この結果も 実験的に確かめることが必要になる.

3 つ目は，2つの音がいつも重なっていなければな らないことである. ある点, 例えば消音器の出口にお いて，2つの音が常に重なっているためには，2つの 音の間にいつも $\frac{\lambda}{2}\left(=\frac{c}{2 f}\right)$ だけの空間的ずれが必要 であるが, 音速 $c$ は温度や流速によって変るので, こ れらが変動する場合には音が大きくなることもある． したがってこれが常に一定に保たれるように，例えば 出口にマイクロホンを設置し, その位置で常に音圧レ 
ベルが最小になるように，スピーカからでる音を制御 することが必要になる。

干渉による消音は古くから知られていたが，これが 最近再びとり上げられるようになったのは, 最近の制 御技術，信号処理技術などの進歩によって，この制御 が比較的容易にまた安価にできるようになったからで ある。

最後の 1 つは, 付加音源の実用性に関することであ る. 消音しようとする音の音圧レベルと, 付加音源か らの音の音圧レベルが等しい場合に透過損失はもっと あ大きくなるが, 消音しようとする音は通常レベルが 大きいので，これに匹敵する音を出す付加音源が必要 になる．またダクト内を高速の気流が通過する場合な どには耐熱性, 機械的強度, さらに音源が長時間連続 運転する機械のような場合には，これに匹敵する耐久 性のある付加音源が必要になる．この点普通のスピー カなどでは実用性に欠けるわけである.

(6) 吹出口消音器

吹出口から高速で流体が吹出す時に発生する騒音の 低减に, 吹出口消音器（表1の6) が用いられる.こ れは吹出口での音の発生状態を変えて音を低減する消 音器である.

吹出口の騒音は吹出口直径のおよそ20倍くらいまで の下流で発生する. 吹出口近くでは高周波, 遠くはな れたところでは低周波数の音が発生する.したがって この消音器は表に示すような構造につくられる.すな わち吹出口に多孔板や金網などをつけ（これをブラス トサプレッサということがある），小さな孔から流体 を吹き出させ，騒音ができるだけ吹出口付近にとどま るようにする。このようにすると吹出流によって発生 する騒音の低周波成分は減衰し，高周波成分は若干大 きくなるが，これはそのあとの吸音ダクト型消音器で 吸音する.そして消音器出口口径は流速を下げるため 入口口径より大きくした構造につくられる。

この消音器のTLは, 一般に簡単に求めることはで きず，通常は実験などにより推定される.

\section{2. 距 離 減 衰}

音源からの音は距離がはなれるにつれて減衰するの で，音源と受音点の距離をはなすことによって騒音を 低減できる，距離による減衰には，音源からはなれる につれて音のエネルギーが拡散することによっておこ る場合と，音源と受音点の間の空気や地表面などによっ て音が吸収されることによっておこる場合があるが，
前者の場合を普通距離减衰といっている．

距離減衰量は，音源の形状，寸法，音の放射状態な どから求められるが， $0 \sim 6 \mathrm{~dB} /$ 倍距離 $(\mathrm{dB} / \mathrm{D} . \mathrm{D}$, D.D : Double distance と書くこともある）の範囲 にある.つまり，距離が 2 倍になるごとに最大 $6 \mathrm{~dB}$ 減衰する。

実際の音源からの音の距離減衰量は, 音源の形状, また音の放射状態などが複雑なため, 一般に求めるこ とはむずかしい．したがって次にのべる仮想的ないく つかの音源を考え，それらの音源からの距離減衰量を 尺度として推定される。

\section{1 点音源からの距離減衰}

無指向性点音源から音がでている場合を考えると (図一 $2(\mathrm{a}))$, この場合の距離減衰量は $20 \log \frac{r_{2}}{r_{1}}(\mathrm{~dB})$ となる. $r_{1}, r_{2}(\mathrm{~m})\left(r_{2}>r_{1}\right)$ は音源中心から任意 の 2 点までの距離である. 距離が 2 倍になるごとに, 騒音レベルは $6 \mathrm{~dB}$ ずつ減衰する.すなわち $6 \mathrm{~dB} / \mathrm{D}$. Dとなる。

実際の音源の場合, 音源の最大寸法の 2 倍くらいの 距離からこのような減衰をすると考えればよい.

音源中心から $r_{0}(\mathrm{~m})$ はなれた点の騒音レベルを Lo $(\mathrm{dB})$ とすると, $r(\mathrm{~m})$ はなれた点の騒音レベル $L_{r}$ は(1)式で求められる.

$$
L_{r}=L_{o}-20 \log \frac{\mathrm{r}_{2}}{\mathrm{r}_{1}}(\mathrm{~dB})
$$

\section{2 線音源からの距離減衰}

無指向性点音源の，無数の集まりとみなせる長さ $l$ （m）の線音源の場合は（図－2(b)），音源中心から中 心に直角な方向の任意の 2 点までの距離を，それぞれ

\section{工場建屋}

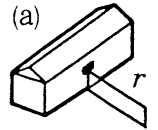

点音源

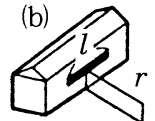

線音源

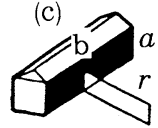

面音源

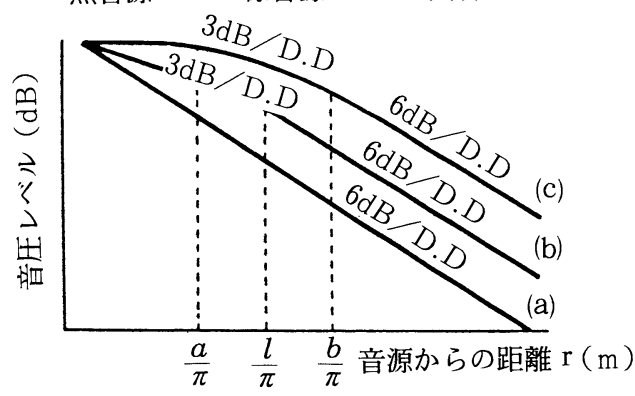

図-2 点, 線, 面音源の距離減衰 
$r_{1}, r_{2}(\mathrm{~m})\left(r_{2}>r_{1}\right)$ とすると, 距離减衰量は(2)式 のようになる.

$$
\begin{aligned}
& r_{2} \leq \frac{l}{\pi} \text { のとき } 10 \log \frac{r_{2}}{r_{1}}(\mathrm{~dB}) \\
& r_{1}>\frac{l}{\pi} \text { のとき } 20 \log \frac{r_{2}}{r_{1}}(\mathrm{~dB})
\end{aligned}
$$

すなわち $\frac{l}{\pi} よ り$ 音源に近い所では，距離が 2 倍にな

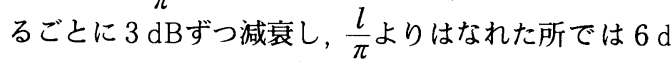
B / D.Dの減衰をする.このような音源では，音源中 心から $\frac{l}{\pi}$ はなれると点音源とみなせる.

線音源の中心から, 中心に直角な方向に $r(\mathrm{~m})$ は なれた点の騒音レベル $L_{r}$ は(3)式で求められる.

$$
\begin{aligned}
& r \leq \frac{l}{\pi} \text { のとき } L_{r}=L_{o}-10 \log \frac{r}{r_{0}} \\
& r>\frac{l}{\pi} \text { のとき } L_{r}=L_{o}-10 \log \frac{l / \pi}{r_{0}}-20 \log \frac{r}{l / \pi}
\end{aligned}
$$

\section{3 面音源からの距離減衰}

無指向性点音源の集まりとみなせる 2 辺の長さが $a$, $b(\mathrm{~m})(b>a)$ の矩形状面音源（図－2(c)）の中心 から, 面に直角な方向の任意の 2 点までの距離を $r_{1}$, $r_{2}$. $(\mathrm{m})$ とすると, 距離減衰量は(4)式で表される.

$$
\begin{aligned}
& r_{2} \leq \frac{a}{\pi} \text { の時 } 0 \\
& \frac{\mathrm{a}}{\pi} \leq r_{1}, r_{2} \leq \frac{b}{\pi} \text { の時 } 10 \log \frac{r_{2}}{r_{1}}(\mathrm{~dB}) \\
& r_{1} \geq \frac{b}{\pi} \text { の時 } 20 \log \frac{r_{2}}{r_{1}}(\mathrm{~dB})
\end{aligned}
$$

$\frac{a}{\pi}$ より音源に近い範囲では, 距離減衰はなく, $\frac{a}{\pi}$ と $\frac{\pi}{\pi}$ の間では $3 \mathrm{~dB} / \mathrm{D} . \mathrm{D}, \frac{b}{\pi}$ よりはなれたところで は $6 \mathrm{~dB} / \mathrm{D} . \mathrm{D}$ 減衰になる.この音源は $\frac{b}{\pi}$ 以上はな れると, 点音源とみなせることになる.

面音源の中心から中心に直角な方向に $r(\mathrm{~m})$ はな れた点の騒音レベル $L_{r}(\mathrm{~dB})$ は, (5)式で求められる.

$r \leq \frac{a}{\pi}$ のとき $L_{r}=L_{0}(\mathrm{~dB})$

$\frac{a}{\pi}<r \leq \frac{b}{\pi}$ のとき $L_{r}=L_{o}-10 \log \frac{r}{a / \pi}(\mathrm{dB})$

$r>\frac{b}{\pi}$ のとき $L_{r}=L_{o}-10 \log \frac{b / \pi}{a / \pi}-20 \log \frac{r}{b / \pi}(\mathrm{dB})$

\section{3. 指向性による減衰}

例えば図ー 3 に一例を示すように音源には指向性が あり, 方向によって放射される騒音のレベルが異なる ので, 受音点のレベルが小さくなるように音源の向き を変えることによってその点の騷音を低減できる．一 般に音の強く放射される方向を受音点と反対になるよ うにすればよい.

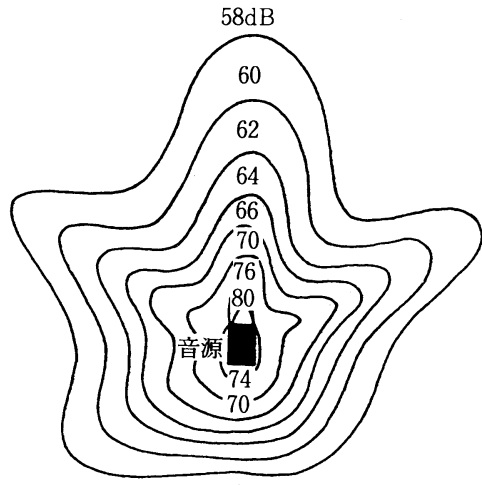

図－3 音源の指向性の一例

向きを変えることによる減音量は，音源中心から一 定距離で音源周囲で測定されたデータなどから求めら れる.

一般に高周波数の音をだす音源や放射面積の大きい 音源は比較的鋭い指向性をむつのでこの方法は有効で ある. 90度方向を変えるだけで10〜 $20 \mathrm{~dB}$ 程度の減音 が得られる場合も少なくない。

\section{4. 空気の吸収による減衰}

音は空気中を伝わるとき, そのエネルギーを空気に 与えるので減衰する．すなわち吸音される．吸音は空 気の粘性や熱伝導, 空気分子の運動状態の变化などに よって生じる.

空気の吸収による減衰量を求める方法はいくつか発 表されているが，それらによると，減衰量は高周波以 外また長距離伝搬以外は一般に, 無視できる程度であ る.

簡略に減衰量を求める方法としては(6)式があるが, 一例としてこれからオクターブバンド中心周波数ごと に $100 \mathrm{~m}$ あたりの減衰量 $\Delta L_{100}(\mathrm{~dB})$ を求めてみると 表 2 のようになる． 数百 $\mathrm{m}$ 以内の音の伝搬を考える場 合には, 通常 $1,000 \mathrm{~Hz}$ 以下の減衰は無視できることが わかる。

$$
\begin{aligned}
& H(1.8 t+32) \geqq 4000 \text { の場合 } \\
& \Delta L_{305}=\frac{f_{i}}{500}(\mathrm{~dB}) \\
& H(1.8 t+32)<4000 \text { の場合 } \\
& \Delta L_{305}=\frac{f_{i}}{750}\left(5.5-\frac{H(1.8 t+32)}{1000}\right)(\mathrm{dB}) \\
& \text { ここで, } H: \text { 相対温度 }(\%) \\
& t: \text { 温度 }\left({ }^{\circ} \mathrm{C}\right) \\
& \Delta L_{305}: 305 \mathrm{~m}(1000 \mathrm{ft}) \text { あたりの減衰量 }
\end{aligned}
$$

$(\mathrm{dB} / 305 \mathrm{~m})$ 
表 2 空気吸収による减衰量

\begin{tabular}{r|r|c|c|c|c|c|c|c}
\hline \hline \multicolumn{1}{|c}{ オクターブバンド中心周波数 $f i(\mathrm{~Hz})$} & 125 & 250 & 500 & 1000 & 2000 & 4000 & 8000 \\
\hline$\Delta L_{100}(\mathrm{~dB} / 100 \mathrm{~m})$ & $\begin{array}{r}\mathrm{H}(1.8 \mathrm{t}+32) \geqq 4000 \\
10^{\circ} \mathrm{C}, 80 \% \text { 以上 } \\
20^{\circ} \mathrm{C}, 60 \% \text { 以上 } \\
30^{\circ} \mathrm{C}, 50 \% \text { 以上 }\end{array}$ & 0.08 & 0.16 & 0.32 & 0.65 & 1.3 & 2.6 & 5.2 \\
& $\mathrm{H}(1.8 \mathrm{t}+32)<4000$ & $0.0065 \mathrm{k}$ & $0.013 \mathrm{k}$ & $0.025 \mathrm{k}$ & $0.045 \mathrm{k}$ & $0.09 \mathrm{k}$ & $0.18 \mathrm{k}$ & $0.35 \mathrm{k}$ \\
\hline & 若 & \multicolumn{6}{|c|}{$\mathrm{k}=5500-\mathrm{H}(1.8 \mathrm{t}+32)$} \\
\hline
\end{tabular}

$f_{i}:$ オクーブバンド中心周波数 $(\mathrm{Hz})$

である。

\section{5．気温，風による減衰}

地上付近の気温が高く，上空の気温が低い場合，伝 わる音の滅衰量は逆の場合にくらべて一般に大きくな る．また風上方向に伝わる音の減音量は，風下方向に 伝わる音の減音量にくらべて大きくなる.

図ー4 に示すように例えば, 音が温度 $t_{1}\left({ }^{\circ} \mathrm{C}\right)$ の部 分から $t_{2}\left({ }^{\circ} \mathrm{C}\right)$ の部分へ, 入射角 $\theta_{i}$ で入射した場合, 屈折角を $\theta_{t}$ とすると, 次の関係が成立つ.

$$
\frac{\sin \theta_{i}}{\sin \theta_{t}}=\frac{c_{1}}{c_{2}} \fallingdotseq \frac{331.5+0.6 t_{1}}{331.5+0.6 t_{2}}
$$

ここで $c_{1}, c_{2}$ :それぞれの部分における音速 $(\mathrm{m} / \mathrm{s})$ である.この式で $t_{2}>t_{1}$ とすると $\theta_{t}>\theta_{i}$ となり，入 射した音は下方へ曲ることになる，空気の温度が連続 的に変化すれば，連続的に屈折することになる．空中 の音の伝搬においては，普通大気温度は上空ほど低い ので，上空ほど音速は小さく，したがって水平に伝わ る音は図ー5(a)のように上方に屈折し遠方への伝搬は 妨げられる。しかし上空に高音層ができるような気象 条件の下では, 音は(b)のような下方に屈折し，比較的 遠距離まで伝わる。

また上空ほど風が強く吹く場合は(c)に示すように， 風下に向って進む音は上空ほど見かけの音速が大きく なるので下方に屈折し, 風上に向って進む音はその反

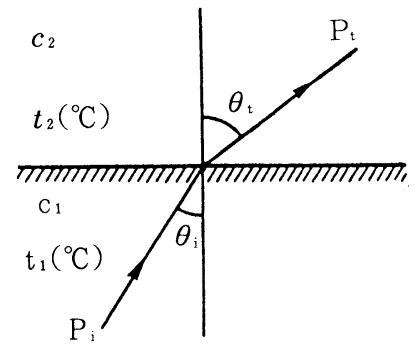

図-4 音 の屈折
対になるので上方に屈折する.

風速 $4.5 \mathrm{~m} / \mathrm{s}$ の場合, $1000 \mathrm{~Hz}$ の音の風のみによる減 音量は, 音源から約 $1 \mathrm{~km}$ はなれた風下ではほとんどな

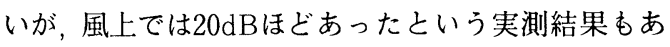
る.

\section{6. 地表面の吸収による減衰}

音が地面に沿って伝わる場合, 音の伝搬は地表面の 状態（凹凸や音響特性など）によって影響を受ける。

地表面が吸音性の場合は，その面に沿って伝搬する 音のエネルギーは吸収されて減衰し，地面に凹凸があ る場合には，その凹凸の寸法と同等以下の波長の音は 散乱されて減衰する。

地表面による音の吸収については, 明確な結果は得 られていないが，一般的にいえることは次のようなこ とである

草地や畑など，また新雪の積った時などのように吸 音性の大きい地表面では，一般に距離减衰よりさらに 大きい減衰が得られる。

$30 \mathrm{~m}$ の草の上を $1000 \mathrm{~Hz}$ の音が伝わる時, $0.7 \mathrm{~dB} / 10$ $\mathrm{m}$ 程度の滅衰である。一方コンクリートやアスファル 卜舗装面などの反射性の地表面の場合は，距離减衰之 ほぼ同じ程度の減衰になる。

地表面の吸収による減衰は距離にほぼ比例すると考 えられる。

実際問題においては，減衰量は問題とする地表面ま たは類似の地表面における実測結果（距離減衰および 空気の吸収による減衰を含む）加推定される。

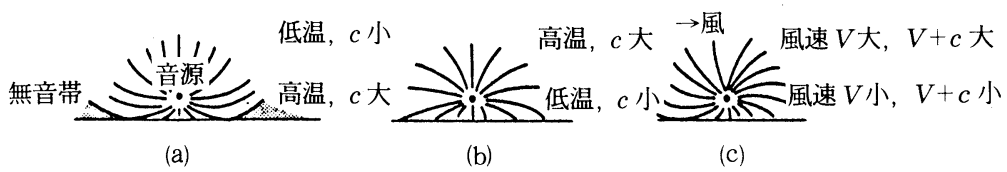

図－5 空中の音の伝搬 


\section{7. 樹木による減衰}

音が伝わるとき途中に樹木が密集していると，音は 反射，吸収などによってェネルギーを失い隇衰する。 減衰量は音の周波数, 樹木の種類, 葉のしげり具合な どによって異なる.

樹木による音の減衰に関してはいくつかの測定，実 験，調査結果がある．例えば松や杉の中を音が伝わる 時の減衰量は $1000 \mathrm{~Hz}$ で約 $3 \mathrm{~dB} / 10 \mathrm{~m}$ というような実 測結果すあるが，これらの結果を総合すると，葉の密 度の大きい樹木では，およそ $50 \mathrm{~m}$ で $10 \mathrm{~dB}$ 程度の減音 が得られている。したがって通常の騒暗防止対策にお いては，減衰量は無視できるほど小さいと考えてよい． 道路端に植えられた並木程度では心理的効果は別とし て，減音効果を期待することはできない，

なお以上のうち 4,5 については気象条件を的確に 測定することは困難であるので，減衰量を量的に求め ることはむずかしく，またこれらを防止技術として活 用することも一般に困難である。

\section{8: マスキング}

騒音防止に関する感覚的手段としてはマスキングの 活用が主なものになる。

\section{1 マスキングとその性質}

マスキングとは音を音でマスクする，すなわちかく すことである．例えば静かなところで話しているとき， 近くで大きな騒音がでると話声は聞こえなくなる。し かし少し大きな声で話をすると，また聞こえるように なる．この場合, 話声は騒音によってマスクされたと いい，この騒音を妨害音（マスカー）とよんでいる. そして騒音のなかでも同じように話ができるように声 を大きくした分，すなわち最小可聴值の上昇量 $(\mathrm{dB})$ をマスキング量とよんでいる。これはマスキングの程 度を表すのに用いられる。

マスキングの程度はマスカーの周波数によって異な る.

純音による純音のマスキングの一例を図ー6に示す． マスカーより周波数の低い音はマスクされにくく， 周波数の高い音はマスクされやすいことがわかる.

またバンドノイズによる純音のマスキングの一例を 図ー 7 に示す．純音の場合と異なってマスカーの中心 周波数より低い音と高い音の両方が，ある範囲にわたっ て山形にマスクされる.このように音を音によってか くすことができるわけである.

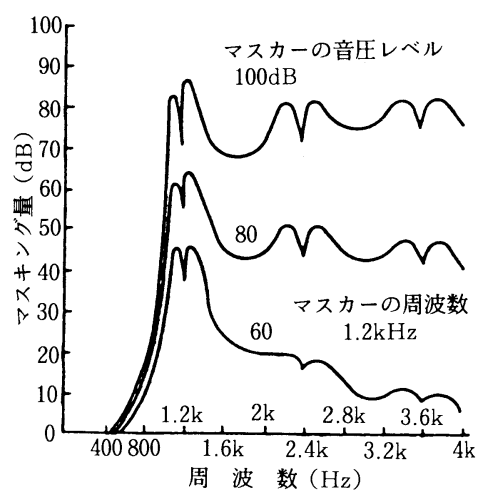

図ー6＼cjkstart純音による純音のマスキングの例

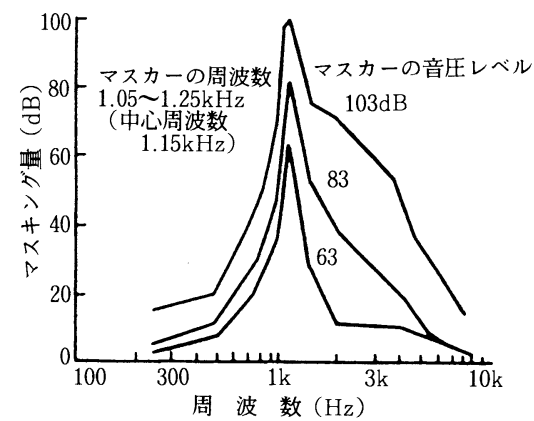

図ー7 バンドノイズによる純音のマスキングの例

\section{2 マスキングの利用}

マスキングは本来, 主として会話の聴取妨害という 騒音の影響という見地から扱われてきたが，次に示す ように, 騒音防止やその他の色々な場合にも利用され ている

テレビで，座頭市がやくざと立ちまわりを演じてい るのがあった，相手は太鼓をたくさん用意して，まわ りでドンドンと大きくたたいている，座頭市はその中 で必死に頭をめぐらせている，これは動きまわる音を 聞こえないように太鼓の音でマスクしているわけであ る.

ガードを電車が通るときの音や音楽の大きな音で, ピストルの音をマスクすることはよく映画にでてくる．

トイレでの音をマスクするのに，水洗の水を流すこ ともよくやられる. 最近は白色騒音を利用した疑似水 流音発生器が市販されている.

機内では騒音レベル80dBくらいの音がでているが, 時々原稿を書いている人を見かける．筆者むよくやる が, 周りの話声などがこの音によってマスクされ，気 にならず集中できる。

単純な仕事をする時，音楽を小さく流すと気がまぎ 
れ，またリラックスして能率もあがる.

集合住宅などで，静かになって近隣の音が気になる 場合には, 音楽を小さく鳴らしてマスクすると気にな らなくなる。

来客の時など静かに音楽を鳴らし, 部屋を音で「飾 る」と, 家の中のちょっとした音がマスクされ落ち着 き，また豊かな感じにもなる。

夜寝る時, 周囲が静かになって, 遠くに聞こえる車 の音が耳について眠れない時など，夕イマーをつけ， 寝つくまでクーラーのファンをまわし，サーという風 の流れる音を出して，車の音をマスクすると寝つける．

近くに空港があるテニス会場では, 真上を低空で通 過する航空機の騒音が大きく，打球音がマスクされ聞 こえなくなるので，プレーがしにくいといわれる．

最近は各種の自然環境音が録音されたカセットテー プが市販されており, 騒音のマスキング, ストレス解 消, 環境づくりなどに利用されている.

またこれはマスキングとちょっと違うが，何かに熱 中していると音が気にならなくなることがある．音が 気になる時には, 何か興味のあることを思い浮かべて 集中すると気にならなくなる．

マスキングを騒音の防止に利用する場合には，音を 出して音をマスクするわけであるから，騒音レベルの 大きいやかましい音に対しては一般に利用できないが， 生活騒音や近隣騒音問題にみられるレベルは小さいが 気になる，という騒音の場合には有効である。

\section{9. 心理的手段}

これは, 騒音問題をおこさないようにするための心 がけ，また問題がおこった場合にトラブルなく，その 問題を解決するための心がけに関することである.

例えば音楽の音は, 楽しむ時には大きくしても, 聞 く自分にとっては騷音にならないが，寝る時には小さ くしても騒音になる. また自分が楽しんでいる時, 他 人が本を読んでいるとすると, その人はこの音楽を騒 音と思う.また反対の場合むある.

音をだす側を加害者, 聞く側を被害者とすれば，こ れからわかるように, 騒音問題においては, 誰であ加 害者になり，また被害者になる。そして騒音問題は, 一般に加害者に対する被害者の苦情という形でおこる. 加害者になる場合を考えてみると，この場合は次の 3つが考えられる.

すなわち，(a)例えば大きな騒音を出し，自分もこれ を認めている，明らかに加害者である場合，(b)例えば 住宅の隣りで建設工事をする場合のように，技術的に 騒音低減が不可能に近いが, 工事をせざるを得ないと いう，加害者にならざるを得ない場合，(c)例えば集合 住宅などで，ドアをバタンと閉めた時の音のように， 自分では気にしていないが, 聞く人が非常に気にする 場合である.

いずれの場合も苦情によって, 問題がおこったこと を知ることになる。したがって騒音問題をおこさない ようにするためには，このような加害者にならないよ うにすることがまず必要である.

次に問題がおこった時には，これを解決するために， 相手とトラブルをおこさないような対処の仕方を考え ることが必要である。

被害者になった場合, 加害者に対して苦情をいうこ とになるが，この場合，いう人もいいにくいが，いわ れる人も加害者であっても一般に気分がよくない．

しかし騒音問題においては，苦情をはっきりさせ， これを解消することを考えなければ問題の解決になら ない。したがって騒音問題においては，トラブルをお こさないように苦情をいい，また苦情を受けるにはど うするかということが, 根本的な課題になる.

これはもちろん場合によって異なるが，現実的な対 応として次のような処置がとられている.すなわち， 加害者になると考えられる場合には，事前に被害者の 状況（性別, 年齢, 気質, 健康, 態度, 習慣, 利害, 職業など）を調べ，その心理を十分考慮した上で，あ いさつ，話し合い，また補償などの処置がとられる．

また被害者になった場合には，被害者であっても， 同様に加害者の状況などを十分調べ，苦情のいい方に ついて十分検討した上で対処する.

以上にのべたことは，工場騒音，建設工事騒音問題 などはもとより，生活騒音，近隣騒音などあらゆる騒 音問題についていえることである

以上 3 回にわたって騒音防止技術の概要についての ベた.

騒音防止対策は，これらの防止技術を使って問題を 解決することであるが，防止技術は本講座 7 の表 1 に 示すものしかないので，このどれもが使用できない場 合には問題は解決しない. その場合には使用できない 原因をとりのぞく必要がある．例えば対策費用の問題, 防音装置の設置場所の問題などを前もって解決してお くことが必要である。 